\title{
Studies on the anti-inflammatory and analgesic properties of Jatropha curcas leaf extract
}

\author{
Johnny O. Olukunle ${ }^{1}$, Olubukola T. Adenubi ${ }^{1}$, Gbenga M. Oladele ${ }^{2}$, \\ Emmanuella A. Sogebi ${ }^{3}$, Patience C. Oguntoke ${ }^{1}$ \\ ${ }^{1}$ Department of Veterinary Physiology and Pharmacology, College of Veterinary Medicine \\ University of Agriculture, Abeokuta, Ogun State, Nigeria \\ ${ }^{2}$ Department of Veterinary Pharmacology and Toxicology, University of Abuja, Abuja, Nigeria \\ ${ }^{3}$ Department of Veterinary Surgery and Reproduction, College of Veterinary Medicine \\ University of Agriculture, Abeokuta, Ogun State, Nigeria
}

Received November 27, 2009

Accepted June 1, 2011

\begin{abstract}
The anti-inflammatory and analgesic properties of the aqueous extract of Jatropha curcas leaves were investigated. Anti-inflammatory effect was studied using acute rat model (carrageenan -induced rat paw oedema) in which aspirin at $150 \mathrm{mg} \cdot \mathrm{kg}^{-1}$, indomethacin at $10 \mathrm{mg} \cdot \mathrm{kg}^{-1}$ (both are standard anti-inflammatory drugs) and aqueous extract of Jatropha curcas leaves at $150 \mathrm{mg} \cdot \mathrm{kg}^{-1}$ were administered orally to 24 Wistar rats $1 \mathrm{~h}$ before induction of oedema and compared with a negative control given $10 \mathrm{ml} \cdot \mathrm{kg}^{-1}$ saline. Using the same dose of the plant extract, the analgesic effect of the aqueous extract of Jatropha curcas leaves was also investigated by measuring the number of acetic acid-induced writhing in 18 mice. The mean percentage inhibition of paw volume of rats treated with indomethacin was $83.9 \%$ followed by aspirin treated group with $64.3 \%$, and the Jatropha curcas treated group with $60.7 \%$. The mean number of writhing was significantly lower $(P<0.05)$ in mice given aqueous extract of Jatropha curcas leaves $(34.0)$ compared to the control group (55.8) but higher than that of the standard analgesic, paracetamol (23.5). This result suggests that Jatropha curcas has anti-inflammatory and analgesic properties comparable with those of standard drugs and may be useful for the treatment of painful inflammatory conditions.
\end{abstract}

Plant extract, anti-nociceptive, carrageenan, oedema, writhing

Inflammation is a complex biological response of vascular tissue to harmful stimuli caused by injury, infection, environmental agents, malignancy and cellular changes. It is a protective attempt by the body to remove the injurious stimuli as well as initiate the healing process for the tissue (Denko 1992). The inflammatory response is a complex process that includes activation of white blood cells, the release of immune system chemicals such as complements and cytokines, and the production and release of inflammatory mediators and prostaglandins (Cotran et al. 2001).

Inflammation may be acute or chronic depending on the disease course. Acute inflammation is characterized by heat, erythema, pain, swelling and loss of function. Pain is a common and distressing feature of many diseases and analgesics relieve pain by acting in the central nervous system or on peripheral pain mechanisms, without significantly altering consciousness. Chronic inflammation on the other hand results in a progressive shift in inflammatory cells characterized by simultaneous destruction and healing of the injured tissue.

Many plants have long been recognized as important sources of therapeutically effective medicines (Newman et al. 2003). Herbs such as Tithonia diversifolia and Carum copticum (Owoyele et al. 2003; Thangam and Dhanajayan 2003) have been shown to possess anti-inflammatory and analgesic effects and such plants can be used as sole therapy in managing inflammatory conditions or as complementary therapy allowing patients to take smaller doses of conventional anti-inflammatory drugs, thereby minimizing the side effects of these drugs.

Address for correspondence:

Johnny Olufemi Olukunle

Department of Veterinary Physiology and Pharmacology

College of Veterinary Medicine

University of Agriculture, Abeokuta, Ogun State, Nigeria
Phone: 234-080-33807215

E-mail: drfaks@yahoo.com

http://www.vfu.cz/acta-vet/actavet.htm 
Jatropha curcas, belonging to the family Euphorbiaceae is an herbal plant known as "lapalapa" in the South Western part of Nigeria and widely distributed in Central and South America, Africa, India and South East Asia (Cano-Asseleih 1986; Cano-Asseleih et al. 1989). It has been used traditionally in the treatment of wounds, burns, and cuts for its antimicrobial and antifungal properties. These claims have not been scientifically analyzed. Furthermore, most conventional anti-inflammatory drugs act by suppressing rather than abolishing inflammation and are well known for their long-term side effects. This study is therefore aimed at investigating the anti-inflammatory and analgesic properties of the aqueous extract of Jatropha curcas leaves.

\section{Materials and Methods}

Plant material and preparation of extract

The leaves of $J$. curcas were obtained from Apakila area in Abeokuta, Ogun State and verified by botanists at the Forestry Research Institute of Nigeria, (FRIN) Ibadan, Oyo State, Nigeria; a specimen of this plant was deposited at this institute.

The leaves were air-dried, pulverized, finely sieved and soaked in 21 of distilled water for $24 \mathrm{~h}$, after which it was filtered. Thereafter, the filtrate obtained was freeze-dried and the percent yield was $2.4 \%$. This sample was stored in the refrigerator until used in the experiment.

Drugs

Aspirin, indomethacin, and paracetamol were purchased from a registered chemist in Abeokuta, Ogun State.

Animals

Eighteen specified pathogen free Swiss mice of either sex weighing $25 \mathrm{~g}$ and 24 specified pathogen free Wistar rats of either sex weighing 150-200 g were used for this study. The animals were kept at the Animal House, College of Veterinary Medicine, University of Agriculture, Abeokuta. They were acclimatized to laboratory conditions for 2 weeks prior to the experiment during which they were introduced to growers mash (Vital feeds Limited, Ibadan, Nigeria). The animals were fed this mash and provided water ad libitum throughout the study. The housing provided had the following conditions: controlled lighting of $12: 12 \mathrm{~h}$ of light: dark, temperature of $25^{\circ} \mathrm{C}$ and relative humidity of approximately $50 \%$. Animal experimentation protocols conformed to the Institutional Animal Ethics Committee's guidelines.

Carrageenan-induced rat paw oedema

Acute inflammation was induced using the carrageenan induced oedema model (Winter et al. 1962). The rats were starved for $24 \mathrm{~h}$ after which they were divided into 4 groups (Groups A-D) of 6 animals each. Rats in group A (negative control, untreated) were given saline at $10 \mathrm{ml} \cdot \mathrm{kg}^{-1} 1 \mathrm{~h}$ before $0.1 \mathrm{ml}$ of $1 \%$ freshly prepared suspension of carrageenan (Sigma Chemical Co.) was injected into the plantar surface of the right hind paw of each rat. Group B rats were given aqueous extract of $J$. curcas leaves orally at the dose of $150 \mathrm{mg} \cdot \mathrm{kg}^{-1} 1 \mathrm{~h} \mathrm{before}$ carrageenan injection. Rats in group $\mathrm{C}$ were given aspirin, a standard anti-inflammatory drug at the dose of $150 \mathrm{mg} \cdot \mathrm{kg}^{-1}$ orally $1 \mathrm{~h}$ before carrageenan injection while group D rats were administered indomethacin, another standard anti-inflammatory drug at a dose of $10 \mathrm{mg} \cdot \mathrm{kg}^{-1}$ orally $1 \mathrm{~h}$ before carrageenan injection.

The linear circumference of the paw was measured after carrageenan injection $(0 \mathrm{~h})$ and $3 \mathrm{~h}$ after carrageenan injection using a loop of thread tied round the paw such that it was neither too loose nor too tight. The length of the thread around the paw was then measured on a ruler and rounded off to the nearest centimetre. The percentage inhibition was calculated according to the formula:

Percentage inhibition $=\frac{\left[\mathrm{C}_{1}-\mathrm{C}_{0}\right]_{\text {contror }}-\left[\mathrm{C}_{1}-\mathrm{C}_{0}\right]_{\text {test }}}{\left[\mathrm{C}_{1}-\mathrm{C}_{0}\right]_{\text {control }}} \times 100$

Where: $\mathrm{Co}=$ Mean paw size at $0 \mathrm{~h}$ after carrageenan injection, $\mathrm{C}_{1}=$ Mean paw size at $3 \mathrm{~h}$ after carrageenan injection

Acetic acid-induced abdominal writhing in mice

This was done as described by Koster et al. (1959). The mice were divided into 3 groups (groups 1-3) of 6 mice each. Distilled water at $5 \mathrm{ml} \cdot \mathrm{kg}^{-1}$ was administered orally to the mice of the control group (group 1), $50 \mathrm{mg} \cdot \mathrm{kg}^{-1}$ paracetamol orally to the mice of group 2 and $150 \mathrm{mg} \cdot \mathrm{kg}^{-1}$ of aqueous extract of $J$. curcas leaves orally to mice of group $3,1 \mathrm{~h}$ before intraperitoneal injection of acetic acid $(0.6 \%$, volume/volume in distilled water, $\left.10 \mathrm{ml} \cdot \mathrm{kg}^{-1}\right)$. The number of writhing exhibited by each animal was counted for $10 \mathrm{~min}$, starting $10 \mathrm{~min}$ after acetic acid injection and computed according to the following formula:

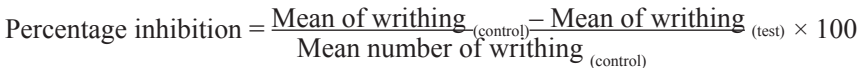


Statistical analysis

Results were expressed as mean \pm SEM. Analysis of the data was done using the one-way Analysis of Variance (ANOVA) followed by the Duncan multiple range test. The $P$ value $<0.05$ was considered significant in all cases.

\section{Results}

Anti-inflammatory test

Aqueous extract of $J$. curcas leaves at a dose of $150 \mathrm{mg} \cdot \mathrm{kg}^{-1}$ exhibited significant antiinflammatory activity in carrageenan induced rat paw oedema model (Table 1). The percentage inhibition in an ascending order is $J$. curcas $(60.7 \%)$ performed comparably to aspirin $(64.3 \%)$ but indomethacin had the highest percentage inhibition value $(83.9 \%)$.

Indomethacin had the highest percentage inhibition of the paw volume $(83.9 \%)$, aspirin caused $(64.3 \%)$ inhibition while the extract of $J$. carcus caused $(60.7 \%)$ inhibition of increase in paw volume a performance well comparable with the standard drug aspirin.

Table 1. Effect of aqueous extract of Jatropha curcas leaves on carrageenan induced paw oedema in Wistar rats.

\begin{tabular}{|c|c|c|c|c|c|}
\hline Groups $(\mathrm{n}=6)$ & $\begin{array}{c}\text { Dose }\left(\mathrm{mg} \cdot \mathrm{kg}^{-1}\right) \\
\text { per os }\end{array}$ & $\mathrm{CBF}(\mathrm{cm}) 0 \mathrm{~h}$ & $\begin{array}{l}\text { CAF }(\mathrm{cm}) 3 \mathrm{~h} \\
\text { paw volume }(\%)\end{array}$ & $\begin{array}{l}\text { Increase in rat } \\
\text { paw volume }(\%)\end{array}$ & Inhibition in rat \\
\hline $\begin{array}{l}\text { Group A } \\
\text { (control, saline) }\end{array}$ & $10 \mathrm{ml} \cdot \mathrm{kg}^{-1}$ & $2.82 \pm 0.05$ & $3.38 \pm 0.04$ & $18.94 \pm 1.32$ & 0 \\
\hline $\begin{array}{l}\text { Group B } \\
\text { (Jatropha curcas) }\end{array}$ & 150 & $2.78 \pm 0.05$ & $3.00 \pm 0.03$ & $7.95 \pm 2.10$ & 60.7 \\
\hline $\begin{array}{l}\text { Group C } \\
\text { (aspirin) }\end{array}$ & 150 & $3.03 \pm 0.05$ & $3.23 \pm 0.04$ & $6.59 \pm 1.22$ & 64.3 \\
\hline $\begin{array}{l}\text { Group D } \\
\text { (indomethacin) }\end{array}$ & 10 & $2.88 \pm 0.03$ & $2.97 \pm 0.03$ & $2.90 \pm 0.58$ & 83.9 \\
\hline
\end{tabular}

Values are Mean \pm SEM

$\mathrm{CBF}$ - Circumference of the rat paw immediately after carrageenan injection $(\mathrm{cm}), \mathrm{CAF}$ - Circumference of the rat paw $3 \mathrm{~h}$ after carrageenan injection $(\mathrm{cm})$.

Table 2. Effect of aqueous extract of Jatropha curcas leaves on acetic acid-induced writhing in mice.

\begin{tabular}{lccc}
\hline Groups $(\mathrm{n}=6)$ & Dose $\left(\mathrm{mg} \cdot \mathrm{kg}^{-1}\right)$ per os & Number of writhing (per 10 min) & Inhibition of writhing (\%) \\
\hline $\begin{array}{l}\text { Group 1 } \\
\text { (control, } \\
\text { distilled water) }\end{array}$ & $5 \mathrm{ml} \cdot \mathrm{kg}^{-1}$ & $55.83 \pm 1.08$ & 0 \\
$\begin{array}{l}\text { Group 2 } \\
\text { (paracetamol) }\end{array}$ & 50 & $23.50 \pm 1.40$ & $57.9^{*}$ \\
$\begin{array}{l}\text { Group 3 } \\
\text { (Jatropha curcas) }\end{array}$ & 150 & $34.00 \pm 1.73$ & $39.0^{*}$ \\
\hline
\end{tabular}

Values are Mean \pm SEM

* Superscripted items are significant at $P<0.05$

Acetic acid-induced abdominal writhing in mice

Aqueous extract of $J$. curcas leaves at a dose of $150 \mathrm{mg} \cdot \mathrm{kg}^{-1}$ also exhibited significant analgesic activity in mice (Table 2). The mean number of writhing was significantly lower $(P<0.05)$ in mice given aqueous extract of Jatropha curcas leaves compared to the control but higher than that of the standard analgesic, paracetamol.

\section{Discussion}

The result of this study suggests that aqueous extract of $J$. curcas leaves has antiinflammatory effect comparable to those of the standard drugs such as aspirin and 
indomethacin. This observation is in line with a similar study carried out by Singh et al. 2008 in which the methanolic root extract of $J$. curcas exhibited systemic and significant anti-inflammatory activity in carrageenan-induced rat paw oedema.

Carrageenan-induced inflammatory process is believed to be biphasic (Vinegar et al. 1969). The initial phase seen at the $1^{\text {st }} \mathrm{h}$ is attributed to the release of histamine and serotonin (Cruckhon and Meacock 1971). The second accelerating phase of swelling is due to the release of prostaglandin, bradykinin and lysozyme. It has been reported that the second phase of oedema is sensitive to both clinically useful steroidal and non-steroidal anti-inflammatory agents (Katzung 1998). The anti-inflammatory activity exerted by aqueous extract of $J$. curcas leaves suggests that it could affect kinnin, prostaglandin, bradykinin and lysozyme synthesis.

The presence of alkaloids and flavonoids in plants has been found to exert active antiinflammatory effects. Studies on the phytochemical analysis of $J$. curcas by Singh et al. (2008) have revealed the presence of alkaloids and flavonoids in the plant.

The analgesic effect of $J$. curcas plant was also noticed. Berkenkopf and Weichman (1988) reported that several chemicals such as phenylquinone and acetic acid could induce a writhing response in laboratory animals. Intraperitoneal injection of acetic acid in this experiment produced abdominal writhing response which was inhibited by aqueous extract of $J$. curcas leaves by $39.0 \%$ as against the standard drug paracetamol which inhibited the writhing by $57.9 \%$.

This result provides a scientific basis for the utilization of this herb in traditional medicine for the treatment of wounds and other conditions that can cause inflammation. Further tests are needed to explore the exact mechanism of action at the molecular level and to know the actual constituents responsible for this activity.

In conclusion, aqueous extract of $J$. curcas leaves could serve as an alternative antiinflammatory therapy in managing inflammatory conditions or as complementary therapy allowing patients to take smaller doses of conventional anti-inflammatory drugs, thereby minimizing the side effects of these standard drugs.

\section{References}

Berkenkopf JW, Weichman BM 1988: Prostagladins 36: 693-701

Cano-Asseleih LM, 1986: Chemical investigation of Jatropha curcas L. Seeds. Ph.D Thesis. University of London. U.K. 290 p.

Cano-Asseleih LM, Plumbly RA, Hylands PJ 1989: Purification and partial characterization of the hemaglutination from seeds of $J$. carcus. J Food Biochem 13: 1-20

Cotran RS, Kumar V, Collins T, 2001: Robbins pathological basis of disease. $6^{\text {th }}$ ed. WB Saunder's company, $51 \mathrm{p}$.

Crunkhon P, Meacock SER 1971: Mediators of inflammation induced in the rat paw by carrageenan. Br J Pharmacol 42: 392-402

Denko CW 1992: A role of neuropeptides in inflammation. In: Whicher JT, Evans SW Biochemistry of inflammation. Kluwer Pub. London, pp. 177-181

Katzung BG, 1998: Basic and clinical pharmacology. $7^{\text {th }}$ ed. Stanford: Connecticut: pp. 578-579

Koster R, Anderson M, De Beer EJ 1959: Acetic acid analgesic screening. Fed Proceed 18: 412

Newman DJ, Cragg GM, Snader KM 2003: Natural products as sources of new drugs over the period 1981-2002. J Nat Prod 66: 1022-1037

Owoyele VB, Wuraola CO, Soladoye AO, Olaleye SB 2004: Studies on the anti- inflammatory and analgesic properties of Tithonia diversifolia leaf extract. J Ethnopharm 90: 317-321

Singh A, Malhotra S, Subban R 2008: Anti-inflammatory and analgesic agents from Indian medicinal plants. Int J Intergr Biol 3: 57

Thangam C, Dhananjayan R, 2003: Anti-inflammatory potential of the seeds of Carum copticum Linn. Indian J Pharm 35: 388-391

Vinegar R, Screiber W, Hugo R, 1969: Biphasic development of carrageenan oedema in rats. J Pharmacol Exp Ther 166: 96-103

Winter CA, Risley EA, Nuss GW 1962: Carrageenan induced oedema in hind paw of the rat as an assay for antiinflammatory drugs. Proc Soc Exp Biol Med (N.Y.) 111: 207- 210 